\title{
Disbelief \\ in Historical Examples
}

\section{The Hampden-Milton-Cromwell passage in Thomas \\ Gray's Elegy Written in a Country Churchyard BÁLINT GÁRDOS}

Abstract: This paper discusses the different conventions of literary didacticism in Gray's Elegy from almost medieval allegorical teaching, replete with capitalized moral qualities ("Ambition," "Grandeur," etc.), through the humanist model of exemplary history (teaching through the powerful rhetorical presentation of turning points in the lives of great men) to a modern model of teaching that is not directed at action but at sympathy evoked through the understanding of socio-economic and cultural forces. The analysis focuses on the transactions between exemplary history and the "annals of the poor" in the poem.

The two probably most familiar critical statements on the poetry of Thomas Gray seem to contradict each other rather sharply. The first is, of course, Samuel Johnson's famous verdict on the Elegy from the concluding words in his life of Gray (1781). "The Church-yard abounds with images which find a mirrour in every mind, and with sentiments to which every bosom returns an echo" (Johnson 1471). The second, by Matthew Arnold, written almost exactly a century later (1880), is part of a critical introduction to Gray's poetry: "'He never spoke out.' In these four words is contained the whole history of Gray, both as a man and as a poet." The first is a dream of perfect communication, the second is a tragic image of almost no communication. Johnson's hope appears to be sustained by the perceived universality of Gray's Christian response to mortality. Arnold's despair springs from his conviction of the hopelessness of serious poetry in an age of prose. While both approaches have found 
followers, neither of them seems to allow for a more detailed examination of how (far) communication happens in the Elegy.

The following essay investigates the rhetorical strategies - by which I mean the strategies of conveying a moral argument - used in Gray's poem. Its argument, briefly, is that most readers pay insufficient attention to the breaks in the Elegy's structure, in order to focus on its supposedly universal moral teaching instead. While there are plenty of studies devoted to the ideological import of Gray's meditation on social difference in the face of the ultimate democracy of death, no analysis that I am familiar with details the radical ruptures in the rhetorical strategies that are used for articulating and maybe inculcating those ideas. In different sections of the poem, Gray addresses the questions related to mortality and social inequality in markedly different ways, testing different rhetorical models and seemingly finding them all wanting.

I will begin with a short discussion of the passage I have indicated in my title and then proceed to compare that passage with other sections in the poem and briefly look at some further examples in Gray's poetry where the difficulty of speaking out assumes precedence over the content of what the "message" might have been.

\section{The Rhetorical Function of History}

Some village-Hampden, that with dauntless breast

The little tyrant of his fields withstood;

Some mute inglorious Milton here may rest,

Some Cromwell guiltless of his country's blood. $(56-60)^{1}$

This section is an exercise in sketching hypothetical histories. Readers usually see it as a thought experiment in a nutshell. What would have happened if the cottagers buried in the country church-yard had been given the advantages of education? Gray is typically assumed to imaginatively measure the losses and gains involved in denying those to large sections of society. We lose great poets, he seems to say, but we are spared murderous dictators. In the wake of William Empson's very influential - although very brief - remarks on the poem in Some Versions of Pastoral, many scholars have commented on the way the supposed advantages and disadvantages

1 Gray's poetry is cited from Lonsdale's Longman edition. 


\section{BÁLINT GÁRDOS}

seem to cancel each other out, leading to a poem that sharply indicates a cruel injustice, but then, according to Empson, "the reader is put into a mood in which one would not try to alter it" (109).

Much less attention, however, has been given to how poorly the iconic names in the quoted stanza do the job of measuring gain and loss. First of all, if they are supposed to represent the two arms of the scales, then why are there three of them (consistently in both the manuscript and the published version)? Secondly, why would Gray use names whose historical associations, whatever the explicit words of evaluation, inevitably overlap? Milton was, of course, not just seen as a great poet, but also as a supporter of Cromwell and while Hampden is here seemingly praised for bravely standing up to tyranny, everyone would have known that his resistance to taxation contributed to turning the antagonism of King and Parliament into armed conflict and thus making Cromwell guilty "of his country's blood."' There was, however, contention even over the evaluation of Cromwell's career. While most agreed in denouncing him as a tyrant and a fanatic, many also emphasized his more likable personal qualities (his braveness and sincerity) and his foreign policy successes. A rather dark myth of "greatness" and "heroism" had thus begun to emerge (Davis 48-52; Howell).

The Eton manuscript had Cato, Tully, and Caesar where the published text has Hampden, Milton and Cromwell. Henry Weinfield, in his essential book-length study of the poem, claims that "the revision is crucial" partly because "it complicates the political (and ethical) associations" linked to the theme of unfulfilled potential. "Cato and Cicero betoken republican virtue, and Caesar, the beginnings of empire, and so with the Roman names there would have been something of a binary opposition between liberty and tyranny. With the shift to an English frame of reference, however, the implication that Cromwell was guilty of his country's blood - and Milton, of course, was Cromwell's Latin secretary - suggests that the stanza cannot be understood in terms of such simple political counters" (89-90). However, in some respects, the shift is not that great: the difference between somebody who, having realized his potential, has proven glorious and somebody who only became guilty of crimes is plainly visible in both the Roman and English references. Moreover,

2 On Milton's troubled reception in the eighteenth century, see e.g. Zwierlein and Kolbrener, on Hampden, see Crawford. 


\section{DISBELIEF IN HISTORICAL EXAMPLES}

the historical associations that accumulate around the given names are also to some extent, maybe to a lesser extent, hazy already in the case of the Roman examples.

There was no consensus over the reading of these classical life stories in Gray's day. According to Louise Marshall, on the one hand, "the Roman Republic was adopted as justification for the Glorious Revolution and became the model to which all parties, indeed all factions aspired" (110), and Cato was often referred to as an embodiment of the values associated with the republic. On the other hand, however, Marshall documents a "shift in focus away from 'the virtuous Republic' to the Rome of insatiable military expansion" (111). She also examines a range of proCaesar works in which the Roman leader is presented as "an appropriate model for British colonial aspiration" (113).

When it comes to the republican heroes, Cicero, as Robert G. Ingram demonstrates, "was a much-appropriated figure. Freethinkers like John Toland and Anthony Collins found in him a kindred spirit, while others, like Herbert of Cherbury and Samuel Clarke, employed him as a tool against Hobbesian materialism" (110). Some Whigs relied on "Cicero's political vision," while others on a "Catonic vision" of politics "and the 1720s and 1730s saw attempts to cast Walpole [the father of Gray's close friend] as a responsible Ciceronian leader" (110). Matthew Fox has described the diversity of the issues and debates that Cicero's name invoked. These include " $[\mathrm{t}]$ he relationship between Cicero as a man and Cicero as a writer; the role of Cicero as a pioneer of religious scepticism; the reputation of Cicero as a stylistic or literary model" (324).

Cato, as Nathaniel Wolloch explains, was often compared to Cicero: "While Cato was considered impractical, Gicero was criticized for being too pragmatic, and the fact that Cicero was murdered and did not end his own life worked in favor of the praise of Cato" (66). However, "Cato's strict virtue could be seen as excessive, while his suicide raised religious questions" (67). There was, therefore, considerable ambiguity present from the start, because the Roman names had already been appropriated for widely different purposes.

While we have no explicit comment by Gray on the shift from Roman to British references, we have his letter of 1761 to his friend Christopher Anstey, who was then translating the Elegy to Latin, on how the "English characters" might be "romanized." "Virgil," he suggested, "is just as good as Milton, and Caesar as Cromwell, but who shall be Hampden?" (Mack 539). The introduction of Virgil's name probably 


\section{BÁLINT GÁRDOS}

indicates, just like the final question, that Gray is hesitant about which names might serve as the best exemplars. Just as importantly, the rather offhand "Virgil is just as good as Milton" might indicate a hint of uncertainty as to what these exemplary figures are supposed to exemplify. While in the Elegy the famous names are accompanied by strongly evaluative thumbnail descriptions, the historical associations triggered by them are invariably too ambiguous for any straightforward didactic statement to emerge. The iconic names do not play their rhetorical functions well.

\section{Changing Rhetorical Strategies}

What is also noteworthy about the Hampden-Milton-Cromwell passage is that it is both preceded and followed by discursive sections of the poem that include or imply strong didactic statements but they indicate dissatisfaction with the deliverance of those messages with abrupt changes in rhetorical strategy.

The section that precedes the one just discussed is based rhetorically on capitalized abstractions. A somewhat preacherly, almost sermonizing voice teaches "Ambition" and "Grandeur" some humility vis-à-vis the "rude forefathers of the hamlet." The language is characterized by distance: the village poor and the capitalized "Proud" aptly think of each other in terms of such abstractions, as Frank Brady observes, since they neither know about nor sympathize with each other. The speaker's self-assured, judgemental voice also suggests a certain detachment from the entire scenario, the rich and famous as well as the poor and obscure are equally discussed in the third person. There is a medieval quality to the danse macabre emphasis on death awaiting everyone in equal measure ("The paths of glory lead but to the grave"). Anne Williams comments on the affinity of all graveyard poetry with the medieval memento mori tradition (108). Cleanth Brooks associated the allegoric figures with the ones which "clutter a great abbey church such as that at Bath or Westminster" (23). This rhetoric, however, immediately breaks down once the topic of unrealized potential and the modern political question of the equality of opportunities are introduced.

The third great didactic movement focuses on the universal human desire to be remembered. Remembered, that is, no longer only through physical memorials but more importantly through a loving connection to people who survive ("On some fond breast the parting soul relies"). The rhetoric of this section is that of sighs 


\section{DISBELIEF IN HISTORICAL EXAMPLES}

and tears. It is based neither on moralizing abstractions nor on historical examples of uncertain relevance to the lives of the villagers, but on an emotionally-charged description of a central moment in the life of a community. The movement of the poem, as Roger Lonsdale has observed, is "towards sympathy" ("The Poetry" 26).

Following readers such as Howard D. Weinbrot, I also believe that the gradual articulation of Gray's sympathy for the village poor and his choice to be buried in their graveyard (repeated, one might add, in Gray's careful arrangements about his own funeral) is the moral centre of the poem. Moralizing, however, is systematically undercut by an emphasis on the rhetorical fragility of the speech situations. We have to remember that after the discursive sections we move to narrative and finally an epitaph. The narrative about the life and death of the fictional poet is spoken "haply" (i.e. perhaps) by "some hoary-headed swain" and is spoken by this hypothetical person to a hypothetical listener in a hypothetical future ("If chance, by lonely Contemplation led, / Some kindred spirit shall inquire thy fate") about a hypothetical past ("like one forlorn / Or crazed with care, or crossed in hopeless love"). The epitaph is actual enough, as much as anything can be in a work of fiction, but its author is not identified, and its reader is the same hypothetical person who is just as alienated from the villagers as the speaker of the poem once was, he too because of his superior education ("thou can'st read") and the fact that he too is not a member of the community.

\section{The Motif of Self-subversion in Gray’s Poetry}

We observe in many important poems of Gray a tendency to undermine the explicit statements and didactic "messages." Linda Zionkowski has analysed what she calls "the speaker's problems with rhetorical strategies" (336) in "Ode on the Spring" and "Ode on a Distant Prospect of Eton College" in excellent detail, but has only short comments on the Elegy. The first ode memorably compares humans to insects and draws a lesson from the similarity which is not unlike the supposed "message" of the Elegy.

To Contemplation's sober eye

Such is the race of man:

And they that creep, and they that fly, 


\section{BÁLINT GÁRDOS}

Shall end where they began.

Alike the busy and the gay

But flutter through life's little day,

In fortune's varying colours dressed:

Brushed by the hand of rough Mischance,

Or chilled by age, their airy dance

They leave, in dust to rest.

Methinks I hear in accents low

The sportive kind reply:

Poor moralist! and what art thou?

A solitary fly!

Thy joys no glittering female meets,

No hive hast thou of hoarded sweets,

No painted plumage to display:

On hasty wings thy youth is flown;

Thy sun is set, thy spring is gone-

We frolic, while 'tis May. (31-50)

Here the "Poor moralist" first reaches a perfectly good and perfectly conventional conclusion about the ultimate insignificance of all our differences in the face of our common destiny, but is, more importantly, then reduced first to the same level as the other insects who are the objects of his sober contemplation and finally even below them, for his inability to enjoy "while "tis May." The speaker effectively loses all authority to moralize and we are left with only two contending perspectives on reality, neither of them evidently preferable to the other (Terry 101-2). In an unusual paradox, the "message" is both said and unsaid, the teaching is there but it is clearly deprived of all its power to create change.

The Eton ode reaches another perfectly good and perfectly conventional moral conclusion about the inevitable interconnectedness of growing up and the experience of pain and disappointment. In this case, quite explicitly, the moral message remains undelivered, because in the famous final lines the speaker decides not to reveal his insight to the children. 


\section{DISBELIEF IN HISTORICAL EXAMPLES}

Since sorrow never comes too late,

And happiness too swiftly flies.

Thought would destroy their paradise.

No more; where ignorance is bliss,

'Tis folly to be wise. $(96-100)$

As in the Elegy, a personal experience is connected to a general moral insight. In both poems, however, the articulation of that insight remains deeply problematic. It almost seems here that the ethics behind the decision to speak or not to speak are ultimately more important than the moralizing content of the preceding contemplation.

I would also like to refer briefly to two other examples, where the emphasis falls not on the choice not to speak out but on the inability to do so. "Mountains, ye mourn in vain" cries the speaker of "The Bard." In vain, that is, because all the other bards have been killed and there is nobody left to voice the pain of occupied Wales. The public inability to mourn repeats Gray's much earlier private and unpublished attempt to voice his private pain in the sonnet on the death of Richard West: "I fruitless mourn to him that cannot hear, / And weep the more because I weep in vain" (13-4).

A historical argument and a deep interest in history seem to lie at the heart of Gray's small poetic oeuvre and his scattered critical thinking on poetry. There is a primitivist argument concerning poetry's super-human capability of "Sailing with supreme dominion / Through the azure deep of air" "The Progress of Poesy: A Pindaric Ode" 116-7), since this is precisely the type of elevation that is denied to the modern poet. The "lyre divine" is "heard no more." Already Dryden's "car" was "less presumptuous" in its flight than those of Shakespeare, Milton and a host of named and nameless poets from classical Southern antiquity and non-classical Northern forbears. As opposed to his close friend Thomas Warton, who inherited his project for writing the first history of English poetry, as David Fairer has shown, Gray typically established historical lines only to display signs of fragmentation and discontinuity. The famous schools of poetry that his sketchy plan establishes also create a mixed case of a view which is historical but contains no model for continuity, no explanation for how one school replaces another (Beresford 373-5). The ancient prophetic or bardic role of the poet is present in Gray's work (especially late in his career), but as far as the present is concerned, this elevated 


\section{BÁLINT GÁRDOS}

public role is only a haunting memory from the past: difficult to let go of, but lacking its erstwhile power altogether.

\section{Summary: The Rhetorical Strugture of the Elegr}

Gray's pervasive interest in rhetorical strategies has been discussed in the literature but their systematic investigation in the Elegy has gone largely unnoticed. I would argue, however, that the problem is emphatically present from beginning to end and sustained attention to it even yields a useful structural description of the poem.

1) The Elegy opens with descriptive stanzas (lines 1-28), evoking, as Suvir Kaul explains, conventions both of pastoral and prospect poetry, but with important differences: the poet here is emphatically distanced from the rural community (the ploughman's work is done, while the poet's is just beginning) and the speaker's vision is limited both by the falling "darkness" and by the fact that he is in no way elevated above the scenery (278-280).

2) Description is followed by three explicitly moralizing sections, which I have already discussed. Gray's dogged attention to questions of rhetoric is shown by the fact that the sections follow a logic of historical development.

2/i) Lines 29-44 are characterized by an allegorical language that evokes the Middle Ages.

2/ii) Lines 45-72 are based on invoking morally and politically meaningful historical examples. This recalls but also complicates the early modern, humanist understanding of the poetic use of historical examples. In Anthony Grafton's concise summary: "Good history narrated past events, in an accurate, prudent, and eloquent way. Readers studied it in the hope of understanding the political calculations of ancient leaders [...] and of sharpening their grasp of moral precepts and their applications, as embodied in crisp, specific historical examples" (11). This tradition strongly associated poetry and history and celebrated poetry's ability to mediate between the vivid representation of a specific instance of behaviour and a general moral rule (Youngren). The problem in this connection is precisely that Gray chooses names where the specificity of moral and political significance is uncertain.

2/iii) Lines 73-96 shift to an idiom typical of Gray's own age, a sentimental code of sighs, tears and the moral problematic of sympathetic identification. This very personal passage no longer pretends to give advice or even to address a broader audience. 


\section{DISBELIEF IN HISTORICAL EXAMPLES}

3) In lines 97-116 we read a "swain's" narrative about the poet, which mostly focuses on the fact that the poet seemingly had no role and no authority in any given community.

4) Finally, lines 117-128 (the epitaph) are characterized by very powerful, evocative language but an extremely fragile rhetorical situation in that the speaker is unidentified, the audience is merely hypothetical and the subject, of course, is dead.

\section{Gonclusions and Context}

Before I finish, I would like to return very briefly to Empson's previously-mentioned critical remarks suggesting that Gray's ostensible interest in the politics of education is spurious. I think we have no reason to suspect Gray of disingenuousness. We have his notes concerning the educational theories recorded in Plato's Republic. We have his unfinished philosophical poem on "The Alliance of Education and Government." We know from the correspondence how enthusiastically he studied Montesquieu; we know of his sustained interest in Rousseau. Thanks to William Mason's Memoirs certain maxims by Gray on social life have survived; these also emphasize the importance of education, e.g. "Any nation that wants public spirit, neglects education, ridicules the desire of fame, and even of virtue and reason, must be ill governed." (Lonsdale, The Poems 91) We also have no reason, I believe, to suspect Gray of naïve sentimentality regarding the innocence of the uneducated either. After all, in a letter of 1763 , he talks of "people without education" as "slaves and mercenaries" (Beresford 256).

Empson talks about readers' irritation by the "complacency in the massive calm of the poem" (109). Instead of calm, we find restless search throughout the poem. Even the turn to God at the end, which many readers have seen as the final "resolution" offered by the poem, contains signs of emotional turmoil in the paradoxical image where the dead "in trembling hope repose." Gray, it seems to me, remains restless and ill-at-ease to the very last and maybe even beyond.

I believe that part of this restlessness results from the lack of a comfortable and practicable rhetorical position that would enable the fulfilment of a conventionally Augustan poetic task, that of confidently teaching and delighting a polite, attentive and available audience. It seems to me that research into the inheritance of the 


\section{BÁLINT GÁRDOS}

humanist tradition of exemplary history is well suited to the examination of a culture that still remembers but is no longer entirely at ease with this model.

The exemplary view of history in the humanist tradition combined an understanding of the moral-political role of literature (by depicting essential turning points in the lives of an established canon of great men, it was meant to provide guidance in the decisions readers needed to make), characteristic aesthetics (the powerful representation of a decisive moment was essential), a hermeneutics (both the writer and the reader were assumed to be able to make the interpretative moves necessary for connecting the specific moment represented, the general principle revealed by the decision and the application of the recognized principle to the specific situation of the reader). The model was usefully contained within a broader rhetoric that the educated members of an elite community would surely have. History was thus seen as an inventory of examples available for delighting, teaching and moving the audience. The model, however, only seems viable with respect to an exclusive community, which could rightfully believe that the decisions of the heroes of, for instance, Plutarch's histories, are directly relevant to their own lives (I offered a general overview of the relevant problems in Gárdos).

Gray's Elegy, of course, directly challenges such anti-democratic ideas and shows interest in the slow processes of the life of the rural community that is usually disregarded by the older narrative. By the modern period, a firmer understanding of cultural diversity (as a result of geographical discoveries, for instance) leads to some scepticism concerning the historical continuity (with classical antiquity) implied by the model. Looking at examples where old patterns are still discernible while the old certainties seem to crumble is, I believe, a fruitful way of examining a culture caught between two rather better-known patterns of historical self-understanding: the old humanist tradition and emerging nineteenth-century historicism.

\section{WORKs Gited}

Arnold, Matthew. "Thomas Gray." The English Poets: Selections with Introductions. Ed. Humphry Ward, Thomas. Vol. I-4. London: Macmillan, I880. 3: 302-316. http://spenserians.cath.vt.edu.

Beresford, John, ed. Letters of Thomas Gray. Oxford: Oxford University Press. 1925. Brooks, Cleanth. “Gray's Storied Urn.” In Gray's Elegy: A Collection of Critical Essays. Ed. Starr, Herbert W. Englewood Cliffs, N.J.: Prentice Hall, I968. 23-32. 
Crawford, Iain. "Wading Through Slaughter: John Hampden, Thomas Gray, and Mary Shelley's Frankenstein." Studies in the Novel, 20.3 (I988): 249-6I.

Davis, J.C. Oliver Cromwell. London: Arnold, $200 \mathrm{~s}$.

Empson, William. "Proletarian Literature." In Gray's Elegy: A Collection of Critical Essays. Ed. Starr, Herbert W. Englewood Cliffs, N. J.: Prentice Hall, I968. I09-IIo.

Fairer, David. "Thomas Warton, Thomas Gray, and the Recovery of the Past." Thomas Gray: Contemporary Essays. Eds. Hutchings, W.B., William Ruddick. Liverpool: Liverpool University Press, 1993. 146-70.

Fox, Matthew. "Cicero during the Enlightenment." The Cambridge Companion to Cicero. Ed. Catherina Steele. Cambridge: Cambridge University Press, 2013. 318-336.

Gárdos, Bálint. "History and Moral Exempla in Enlightenment Aesthetics." Essays in Philosophy. I7.I (2016): 22-54.

Grafton, Anthony. What was History? The art of history in early modern Europe. Cambridge: Cambridge University Press, 2007.

Howell, Roger, Jr. "Cromwell, the English Revolution and political symbolism in eighteenth century England." In Images of Cromwell: Essays for and by Roger Howell, Jr. Ed. Richardson, R.C. Machester: Manchester University Press, I993. 63-73.

Ingram, Robert G. "Conyers Middleton's Cicero: Enlightenment, Scholarship, and Polemic." Brill's Companion to the Reception of Cicero. Ed. Altman, William H. F. Leiden and Boston: Brill, 2015. 95-I23.

Johnson, Samuel. The Lives of the Poets. Vol. 3. The Works of Samuel Johnson. Vol. 2I-23. Ed. John H. Middendorf. New Haven: Yale University Press, 2 oro.

Kolbrener, William. "Reception." In Cambridge Companion to John Milton. Ed. Louis, Schwartz. Cambridge: Cambridge University Press, 2014. I95-210.

Lonsdale, Robert. "The Poetry of Thomas Gray: Versions of the Self." Thomas Gray's Elegy Written in a Country Churchyard. Modern Critical Interpretations. Ed. Bloom, Harold. New York: Chelsea House, 1987. I9-37.

Lonsdale, Roger, ed. The Poems of Gray, Collins and Goldsmith. London: Longman, 1969.

Mack, Robert L. Thomas Gray: A Life. New Haven: Yale University Press, 2000. 


\section{BÁLINT GÁRDOS}

Suvir, Kaul. "Thomas Gray, Elegy Written in a Country Church Yard." A Companion to Eighteenth-Century Poetry. Ed. Gerrard, Christine. Oxford: Blackwell, 2006. 277-289.

Terry, Richard. "Gray and Poetic Diction." In Thomas Gray: Contemporary Essays. Eds. Hutchings, W. B., William Ruddick. Liverpool: Liverpool University Press. I993. 73-IIO.

Weinbrot, Howard D. "Gray's Elegy: A Poem of Moral Choice and Resolution." Thomas Gray's Elegy Written in a Country Churchyard. Modern Critical Interpretations. Ed. Bloom, Harold. New York: Chelsea House, 1987. 69-82.

Weinfield, Henry. The Poet Without a Name: Gray's Elegy and the Problem of History. Carbondale: Southern Illinois University Press, I99I.

Williams, Anne. "Elegy into Lyric: Elegy Written in a Country Churchyard." In Thomas Gray's Elegy Written in a Country Churchyard. Modern Critical Interpretations. Ed. Bloom, Harold. New York: Chelsea House, I987. IoI-II8.

Wolloch, Nathaniel. "Cato the Younger in the Enlightenment." Modern Philology. I06.I (2008): 60-82.

Youngren, William H. "Generality, Science and Poetic Language in the Restoration." ELH. 35.2 (1968): 158-187.

Zionkowski, Linda. "Bridging the Gulf Between: The Poet and the Audience in the Work of Gray." ELH 58.2 (I99I): 33I-350.

Zwierlein, Anne-Julia. "Milton Epic and Bucolic: Empire and Readings of Paradise Lost, I667-I837." In The Oxford Handbook of Milton. Eds. McDowell, Nicholas, Nigel Smith. Oxford: Oxford University Press, 2009. 669-686.

\section{Contributor Details}

Bálint Gárdos is senior lecturer at Eötvös Loránd University (ELTE), Budapest. His teaching mostly covers eighteenth and nineteenth century British Literature. He is the author of a monograph on the genre of the essay in British Romanticism (Földönjáró romantikusok, 2012). This essay is part of his present project: an investigation into the heritage of exemplary history in eighteenth century British literature and aesthetics. 